\title{
IDENTIFIKASI SERANGGA DAN PENYAKIT DI AREAL PERSEMAIAN PT. SARI BUMI KUSUMA DI KECAMATAN BUKIT RAYA KABUPATEN KATINGANKALIMANTAN TEGAH
}

\author{
(Identification Of Insect And Disease In The Seedling Area Of PT. Sari Bumi Kusuma Bukit \\ Raya District, Katingan Regency, Middle Kalimantan)
}

\author{
Yulius Bambang, Farah Diba, Sofwan Anwari \\ Fakultas Kehutanan Universitas Tanjungpura. Jalan Imam Bonjol Pontianak 78124 \\ Email : yuliusbambang150589@gmail.com
}

\begin{abstract}
Seedlings are the first step in providing ready-to-plant seedlings and supporting sustainable forest-building processes. Growth of good quality tree, required seeds healthy, superior and free from pests and diseases in the nursery area. Lack of information on the types of pests and diseases that attack plants in the nursery at PT. Sari Bumi Kusuma KM. 93, it is necessary to identify clearly in order to know the types of pests and diseases that attack and further control measures against pest and disease attacks. Pests are all animals that cause losses to forest trees and forest products such as insects, squirrels, rats, pigs, deer and others. But the reality in the field of potential and explosive pests cause losses is from the insect class. Illness is the deterioration of physiological processes caused by a continuous pressure or disorder of a major (biotic or abiotic) cause that cell or tissue activity becomes abnormal, which is described in a typical pathology form called a symptom or sign. It is these symptoms or signs that indicate whether the tree in the forest is healthy or sick. The pest was found are caterpillar, looper and grasshopper leaves. The deaseas are trunk cancer, fruit tumor, leaves spott, gaal and fungi.
\end{abstract}

Keywords: Nursery, pests, diseases.

\section{PENDAHULUAN}

Hutan merupakan salah satu sumberdaya alam terpenting bagi rakyat Indonesia karena berbagai fungsi dan manfaat yang dimilikinya. Upaya mempertahankan kesinambungan fungsi dan manfaat ini, hutan sebagai kekayaan nasional harus dikelola secara lestari. Persemaian adalah tempat atau areal untuk kegiatan memproses benih (atau bahan lain dari tanaman) menjadi bibit atau semai yang siap ditanam di lapangan. Kegiatan di persemaian merupakan kegiatan awal di lapangan dari kegiatan penanaman hutan karena itu sangat penting dan merupakan kunci pertama di dalam upaya mencapai keberhasilan penanaman benih di lapangan dapat dilakukan secara langsung (direct planting) dan secara tidak langsung yang berarti harus disemaikan terlebih dahulu di tempat persemaian (Pelupessy, 2007).

Keberadaan benih yang berkualitas baik, pengadaan persemaian juga merupakan kegiatan yang sangat penting agar rencana penanaman tidak gagal. Bibit yang sehat dan bermutu baik merupakan modal awal dalam pembinaan kehutanan yang hanya dapat dihasilkan dari persemaian yang dikelola dengan baik. Guna mewujudkan pengelolaan persemaian secara optimal maka kegiatan pengendalian hama sangat perlu dilakukan agar memperoleh bibit yang berkualitas. 
Tujuan penelitian adalah mengidentifikasi jenis-jenis organisme hama yang menyerang tanaman persemaian di PT. Sari Bumi Kusuma.

\section{METODE PENELITIAN}

Penelitian dilaksanakan di areal persemaian PT. Sari Bumi Kusuma Kecamatan Bukit Raya, Kabupaten Katingan, Propinsi Kalimantan Tengah, dengan waktu selama \pm 2 (dua) minggu di lapangan. Penelitian dilakukan dengan metode survei, yaitu dengan menggunakan observasi langsung di lapangan dengan mengidentifikasi jenis hama di areal persemaian PT. Sari Bumi Kusuma di Kecamatan Bukit Raya, Kabupaten Katingan, Propinsi Kalimantan Tengah.

HASIL DAN PEMBAHASAN

\section{A. Serangga}

Berdasarkan hasil identifikasi jenis serangga secara langsung di lapangan yang menyerang tanaman areal persemaian PT. Sari Bumi Kusuma KM. 93 disajikan pada Tabel 1.

Tabel 1. Jenis Serangga yang Menyerang di Areal Persemaian PT. Sari Bumi Kusuma (Types of insect pests that attack the nursery area of PT. Sari Bumi Kusuma).

\begin{tabular}{|c|c|c|c|c|}
\hline \multirow{3}{*}{$\begin{array}{l}\text { No } \\
1\end{array}$} & Ordo & Famili & Jenis serangga hama & Bagian yang dirusak \\
\hline & Lepidoptera & Lasiocampidae & $\begin{array}{l}\text { Ulat bulu } \\
\text { (Macrothylacia rubi) } \\
\text { Ulat jengkal (Plusia }\end{array}$ & Daun, pucuk \\
\hline & & Noctuidae & $s p)$ & $\begin{array}{l}\text { Daun, pucuk } \\
\text { Daun }\end{array}$ \\
\hline 2 & Orthoptera & Tettigoniidae & $\begin{array}{l}\text { Belalang daun } \\
\text { (Scudderia furcata) }\end{array}$ & Pucuk, daun \\
\hline
\end{tabular}

1. Ulat Bulu (Macrothylacia rubi)

Ulat/larva dari ordo Lepidoptera dan famili Lasiocampidae ini menyerang bagian daun dan tepi daun. Daun akan berlubang dan tepi daun terkoyak dengan bekas gigitan yang tidak rata atau bergerigi dan akhirnya tinggal tulang daun yang tersisa. Hal ini akan menghambat pertumbuhan tanaman karena tidak ada proses fotosintesis. Ulat bulu juga merusak bagian pucuk. Hasil pengamatan langsung di lapangan ulat bulu menyerang tanaman areal persemaian PT. Sari Bumi Kusuma KM. 93 pada naungan $50 \%$ dan naungan $25 \%$. Tanaman yang diserang oleh ulat bulu adalah Shorea desyphilla, Shorea leprosula, Shorea johorensis dan Shorea parvifolia. Ulat bulu ditemukan pada naungan $50 \%$ dibeberapa bedeng yaitu pada bedeng nomor 22, 24 yaitu pada tanaman Shorea leprosula, bedeng nomor 132 yaitu tanaman Shorea desiphylla. Ulat bulu ditemukan pada naungan 25\% pada tanaman Shorea leprosula dengan nomor bedeng 02, 38, 45, 103, 123. Tanaman Shorea johorensis ulat bulu ditemukan dengan nomor bedeng 124 dan 164. Tanaman Shorea desiphylla dengan nomor bedeng 144 dan 156, pada Shorea parvifolia dengan noor bedeng 159. Adanya serangan ulat bulu ini maka pertumbuhan tanaman akan terhambat karena menyerang bagian daun yang berakibat pada proses fotosintesis sehingga pertumbuhan tanaman menjadi kerdil bahkan mati. 

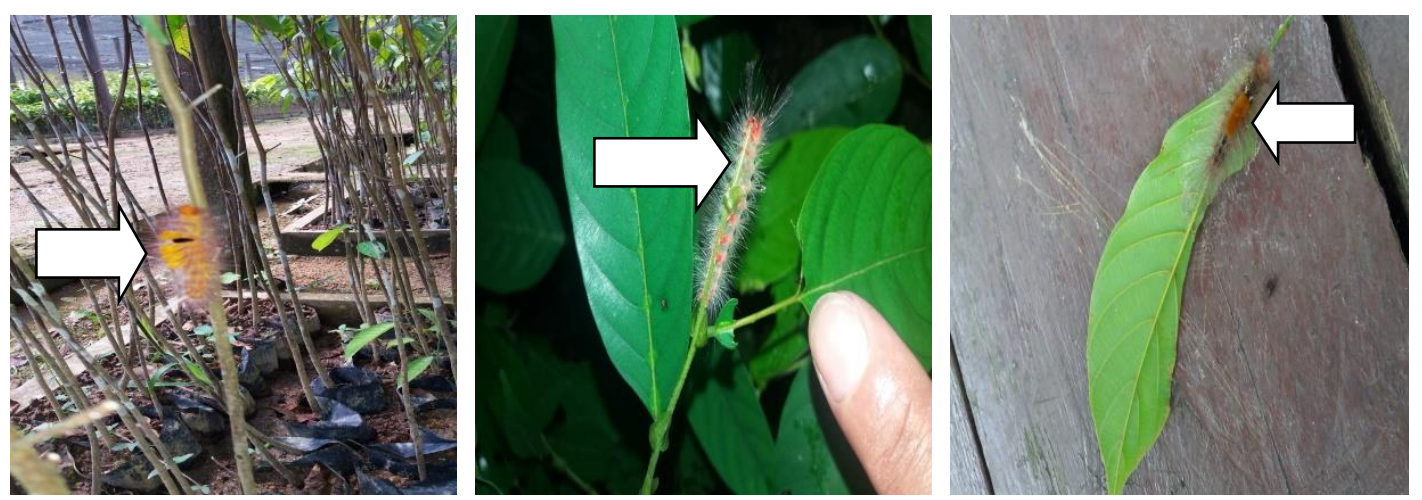

Gambar 1. jenis ulat bulu (Type of caterpillar).

\section{Ulat Jengkal (Plusia sp)}

Ulat atau larva ini tergolong ordo lepidoptera, famili Noctuidae. Ulat ini berwarna kecoklatan dengan garis putih melingkar pada segmen badannya dan ada juga yang berwarna kekuningan dengan panjang kurang lebih 1-1,5 cm. Ulat jengkal ini ditemukan pada naungan $50 \%$ dengan warna kekuningan pada tanaman Shorea leprosula dengan nomor bedeng 22 . Ulat pada naungan $25 \%$ dengan waran kecoklatan, garis putih melingkar badan pada tanaman Shorea johorensis dengan nomor bedeng 65. Ulat jengkal juga menyerang tanaman bagian daun, bekas gigitannya daun terlihat berlubang. Hal ini menyebabkan proses fotosintesis menjadi terhambat sehingga pertumbuhan menjadi terganggu.

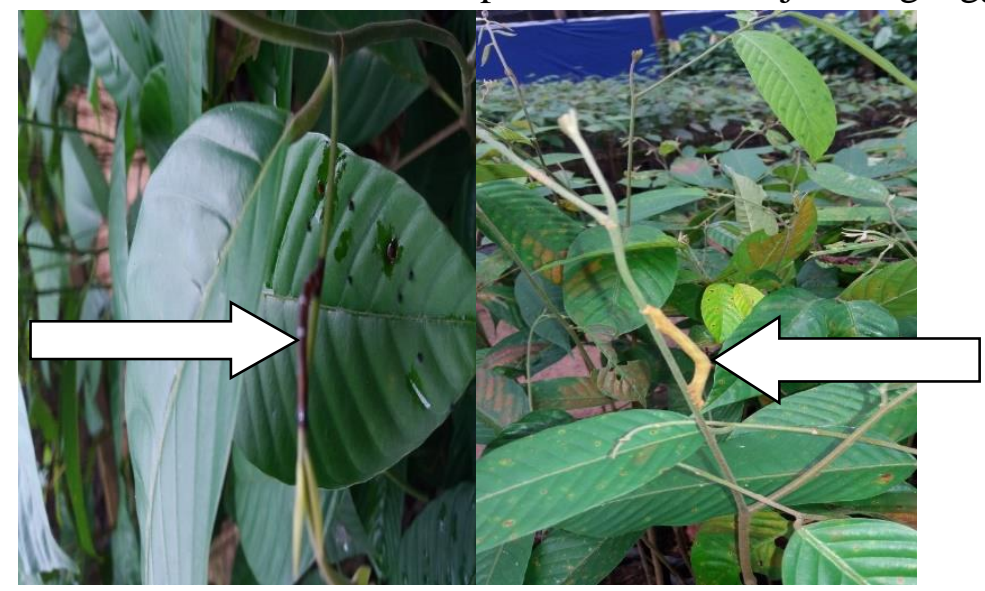

Gambar 2. Jenis ulat jengkal (Types of cricket caterpillars).

\section{Belalang Daun (Scudderia furcata)}

Belalang daun tergolong ordo Orthoptera, famili Tettigoniidae. Menurut Borror (1992) bahwa belalang ini disebut katydid-katydid yang dapat dikenali dengan tidak adanya duri-duri pada prosternum, dan sayap-sayap belakang lebih panjang dari pada sayap- sayap depan. Belalang ini secara normal berwarna hijau tetapi ada juga berwarna ungu. Antena belalang daun sangat panjang (Pracaya, 2003). Belalang ini menyerang pada tingkat dewasa (imago) pada daun muda di tengah daun dan biasanya meninggalkan kotoran yang berwarna hitam. Belalang ini tidak 
ditemukan pada saat penelitian namun terdapat kotoran yang ditinggalkan. Belalang daun menyerang tanaman bagian tengah daun dan tepi duan sehingga menyebabkan daun menjadi rusak dan terlihat berlubang yang tersisa hanya tulang daun saja. Hal ini menyebabkan terhambatnya proses fotosintesis sehingga pertumbuhan tanaman menjadi terhambat jika intensitas serangan cukup tinggi.

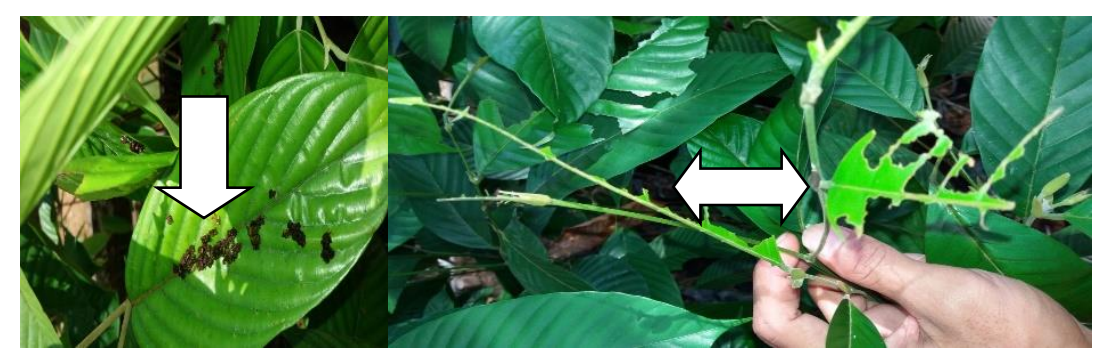

Gambar 3. Kotoran belalang dan bekas gigitan belalang daun (Locust droppings

\section{B. Penyakit}

and leaf grosshopper bites)

Berdasarkan hasil pengamatan langsung terhadap jenis penyebab penyakit dan gejala yang ditunjukan, maka ditemukan beberapa penyakit yang menyerang tanaman persemaian disajikan pada Tabel 2.

Tabel 2. Jenis Penyakit yang Menyerang Tanaman Areal Persemaian PT. Sari Bumi Kusuma (Types of disease that attack the nursery area of PT. Sari Bumi Kusuma).

\begin{tabular}{|c|c|c|c|}
\hline No & Nama Penyakit & $\begin{array}{c}\begin{array}{c}\text { Lokasi terlihatnya } \\
\text { penyakit }\end{array} \\
\end{array}$ & Gejala yang terlihat \\
\hline 1 & Kanker Batang & Pada batang & Batang terlihat membengkak \\
\hline 2 & Tumor Buah & Pucuk, ujung dahan & $\begin{array}{l}\text { Bulat lonjong, runcing dan berwarna } \\
\text { hijau }\end{array}$ \\
\hline 3 & Bercak Daun & Daun & $\begin{array}{l}\text { Bercak hitam bintik besar, kekuningan, } \\
\text { bercak putih seperti tepung }\end{array}$ \\
\hline 4 & Gaal & $\begin{array}{l}\text { Pangkal daun, } \\
\text { pucuk, dan ujung } \\
\text { daun }\end{array}$ & Berduri tumpul seperti buuah rambutan \\
\hline 5 & Jamur & Pucuk/tajuk & $\begin{array}{l}\text { Warna putih keunguan menempel } \\
\text { bagian tajuk }\end{array}$ \\
\hline \multicolumn{4}{|c|}{$\begin{array}{rll}\text { 1. Kanker Batang } & \text { yang terserang. Penelitian ini } \\
\text { Gejala awal penyakit kanker batang } & \text { menunjukan bahwa penyakit kanker } \\
\text { adalah menggelembungnya bagian } & \text { batang umumnya menyerang tanaman } \\
\text { batang atau cabang, kemudian akan } & \text { Shorea leprosula. Akibat serangan } \\
\text { membesar dan busuk sehingga } & \text { kanker batang pertumbuhan tanaman } \\
\text { menyebabkan kerusakan pada tanaman } & \text { khususnya Shorea leprosula tidak stabil }\end{array}$} \\
\hline
\end{tabular}


karena unsur hara yang diangkut melalui batang tidak bisa sampai ke daun, sehingga menyebabkan tanaman menjadi kerdil bahkan mati. Kanker batang juga mempengaruhi pertumbuhan dan riap batang (Rahayu, 1999).

Penyebab penyakit kanker diduga merupakan interaksi antara hama, jamur pathogen, dan perubahan proses fisiologis dari tanaman itu sendiri.

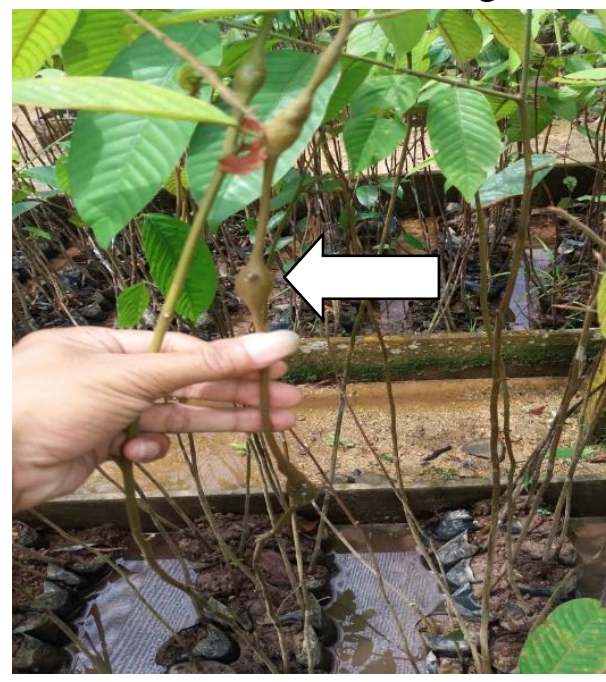

Gambar 4. Penyakit kanker batang (Wood cancer disease).

\section{Tumor Buah}

Gejala serangan tumor buah berupa munculnya tumor yang bentuknya menyerupai buah bulat lonjong pada pucuk tanaman. Tumor tersebut berwarna hijau, kemudian lama kelamaan akan berubah berwarna coklat, apabila tumor tersebut sudah masak atau tua maka tumor tersebut akan pecah. Tumor di dalamnya terdapat serangga kecil beserta telurnya yang berasal dari famili Archanidea. Akibat gangguan tumor ini pertumbuhan tanaman akan terhambat sehingga menyebabkan tanaman kering dan mati (Rahayu, 1999).

Berdasarkan penelitian Arruan (2001) dalam Ngatiman, Armansyah dan Budiono (2008) penyebab tumor buah tersebut adalah serangga (kutu) dengan perantara lalat buah (Agromyzidae, Diptera) yang hinggap di pucuk-pucuk tanaman. Tumor buah mulai terbentuk pada saat kutu-kutu tersebut bertelur dipucuk tanaman. Penyakit tumor buah banyak muncul pada musim penghujan atau cuaca dingin dan waktu tumor buah pecah pada musim penghujan. Faktor lingkungan berperan dalam proses penyebaran penyakit melalui beberapa jalan (Farah, 2013). Sampai saat ini belum ada pengendalian khusus dalam menangani penyakit tumor buah ini, namun pengendalian secara manual dapat dilakukan dengan cara memotong bagian pucuk tanaman yang terserang tumor tersebut. 

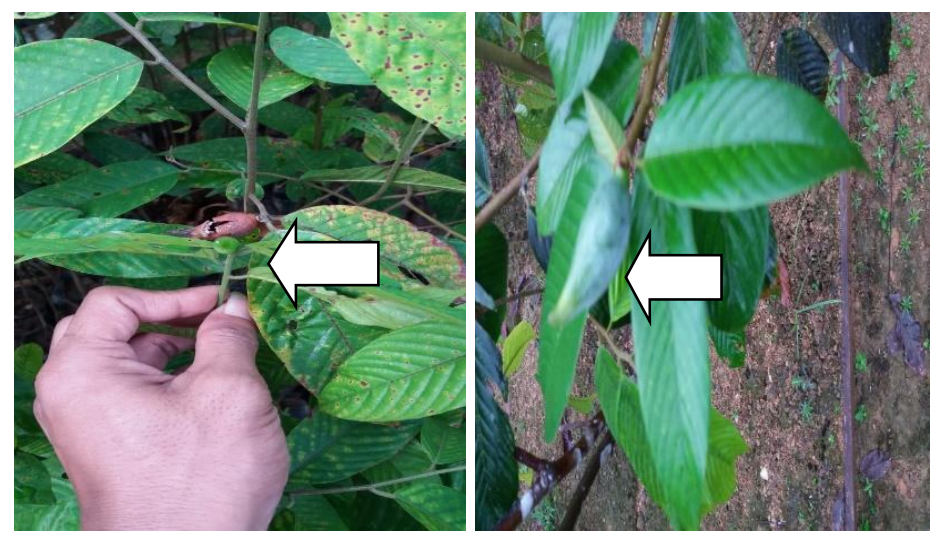

Gambar 5. Penyakit tumor buah (fruit tumour disease).

\section{Bercak daun}

Penyakit bercak daun menyerang hampir semua jenis tanaman di areal persemainan PT. Sari Bumi Kusuma KM. 93. Gejala serangan bercak daun berupa noda pada permukaan daun atau titik bulatan kecil yang tidak beraturan dengan tepi bercak agak menebal dan berwarna lebih gelap dibandingkan dengan bagian tengahnya. Bercak berwarna kuning kecoklat-coklatan, cokelat kemerah-merahan sampai cokelat tua ada juga yang berwarna putih. Beberapa bercak dalam satu daun, bercak dapat saling menyatu membentuk daerah bercak yang luas. Bercak-bercak tersebut juga dapat berkembang dengan cepat membentuk hawar (blight). Daun akan gugur sebelum waktunya apabila intensitas serangan penyakit tinggi, meskipun nantinya akan terbentuk jaringan daun tanaman baru yang sehat. Penyakit tersebut dapat mempengaruhi proses fotosintesis dan pertumbuhan tanaman (Rahayu, 1999).

Penyebab penyakit bercak daun adalah jamur Pestalotia sp. dan Cercospora sp. Kelembaban yang tinggi, tumbuhan bawah, gulma yang rapat, dan tumpukan seresah yang tebal di sekitar tanaman atau persemaian sangat mendukung terjadinya penyakit bercak daun. Jamur-jamur penyebab bercak daun pada umumnya dikenal sebagai parasit fakultatif pada seresah di lantai hutan. Jamur akan berkembang dan menginfeksi tanaman apabila kondisi lingkungan mendukung (Rahayu, 1999).

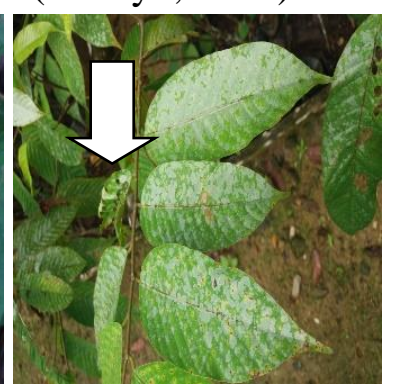

Gambar 6. Penyakit bercak daun (Speckled leaf disease). 


\section{Gaal}

Penyakit ini hampir sama dengan tumor buah berwarna hijau setelah itu akan membusuk berwarna kecoklatan dan di dalamnya terdapat patogenpatogen kecil. Gaal seperti buah rambutan dan berduri menyerang tanaman Shorea leprosula pada areal persemaian PT. Sari Bumi Kusuma KM.93. Penelitian ini menunjukan bahwa gaal menyerang Shorea

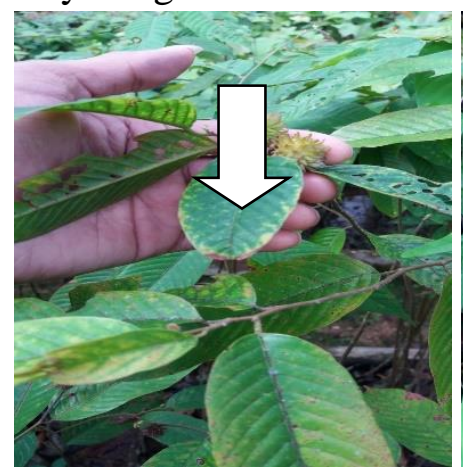

leprosula pada bagian pangkal daun, ujung daun dan ada pula menyerang bagian pucuk. Penyakit ini menyerang tanaman di areal persemaian pada naungan $50 \%$ (penyapihan) dan naungan $25 \%$ (siap tanam). Pengendalian yang dilakukan di areal persemaian PT. Sari Bumi Kusuma terhadap penyakit gaal adalah memotong dan membuang bagian yang terserang penyakit tersebut.

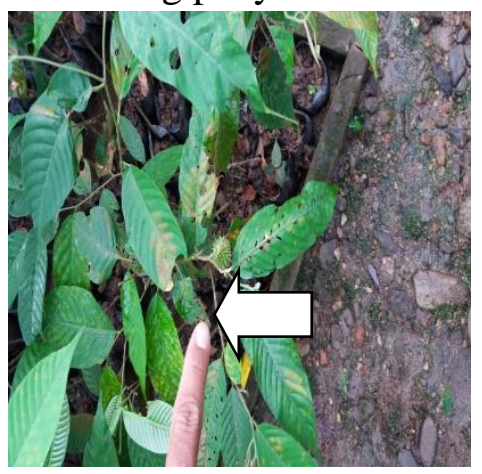

Gambar 7. Penyakit gaal (Gaal disease).

\section{Jamur}

Jamur ini menyerang tanaman di areal persemaian khususnya tanaman Compassia malacensis pada bagian tajuk. Tajuk yang terserang terlihat berwarna putih keunguan. Akibat serangan ini tajuk akan layu dan lamakelamaan akan busuk sehingga bisa menyebabkan kematian pada tanaman itu sendiri. Jamur ini menyerang pada saat musim penghujan, diduga karena kelembaban yang cukup tinggi. Tindakan yang dilakukan di areal persemaian PT. Sari Bumi Kusuma KM.93 adalah dengan menyemprotkan pestisida alami pada bagian yang terserang atau mencabut tanaman yang terserang itu.

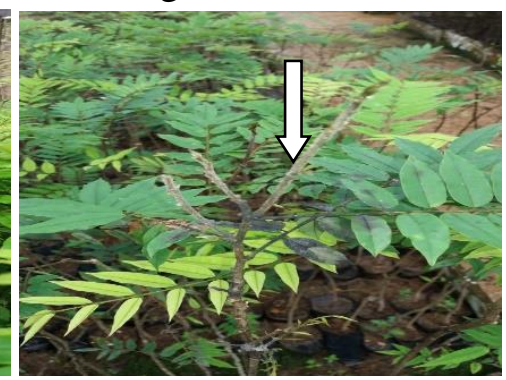

Gambar 8. Penyakit jamur (Mushroom disease). 


\section{Kesimpulan}

Jenis-jenis serangga yang menyerang tanaman di areal persemaian PT. Sari Bumi Kusuma adalah ulat bulu (Macrothylacia rubi), ulat jengkal (Plusia sp), dan belalang daun (Scudderia furcata) yang menyebabkan kerusakan pada daun tanaman. Jenisjenis penyakit yang menyerang tanaman dan menyebabkan kerusakan tanaman di areal persemaian PT. Sari Bumi Kusuma adalah : kanker batang, tumor buah, bercak daun, gaal, dan jamur.

\section{Saran}

Guna melihat jenis serangga dan penyakit yang lebih banyak dapat dilakukan penelitian pada areal persemaian lain. Air yang tergenang dalam bedeng sebaiknya di alirkan atau dibuang untuk mengurangi kelembaban, karena kelembaban yang tinggi mempengaruhi munculnya serangga dan penyakit dan dapat menyebabakan kematian pada tanaman.

Daun sungkai bisa digunakan sebagai bahan pestisida alami selain cabai dan daun pepaya.

\section{DAFTAR PUSTAKA}

Isaniyah, F Diba dan H Darwati. 2013. Karakteristik Penyakit Tumor Buah Pada Tanaman Meranti Merah (Shorea leprosula) Di Kebun Pangkas PT. Sari Bumi Kusuma Kecamatan Serawai Kabupaten Sintang. Jurnal. Fakultas Kehutanan Universitas Tanjungpura.

Ngatiman, Armansah dan Budiono M. 2008. Pemangkasan Cabang Untuk Mengendalikan Serangan Hama Pada Tanaman Shorea
Leprosula Miq. Balai Besar Penelitian Dipterokarpa.

Pelupessy L. 2007. Teknik Persemaian. Pelatihan Penanaman Hutan di Maluku \& Maluku Utara. Fakultas Pertanian Universitas Pattimura.

Pracaya. 2003. Hama Dan Penyakit Tanaman, Kanisius, Yogyakarta.

Rahayu S. 1999. Penyakit Tanaman Hutan di Indonesia (Gejala, Penyebab dan Teknik Pengendaliannya). Penerbit Kanisius. Yogykarta.

Rahayu S. 1998. Penyakit pada Tanaman Meranti. Penyakit Tanaman di Indonesia. Kanisius. 